\title{
DESENVOLVIMENTO DE UM PROGRAMA EDUCATIVO SOBRE SAÚDE DO TRABALHADOR (EDUCAS@T) PARA PROFISSIONAIS QUE ATUAM NO NASF-AB
}

\author{
AUTOR: MARIANA MEDRADO MARTINS \\ CO-AUTOR: BRENDA SANTANA ALMEIDA \\ CO-AUTOR: GRASIELY FACCIN BORGES \\ CO-AUTOR/ORIENTADOR: MARIA LUIZA CAIRES COMPER
}

\begin{abstract}
Resumo: INTRODUÇÃO: As equipes da Atenção Básica fundamentam a integralidade da atenção à Saúde do Trabalhador. As lesões musculoesqueléticas representam a doença ocupacional mais prevalente do mundo. Entretanto, as ações em ST pela AB são pouco executadas ou inexistentes, principalmente por falta de capacitação dos profissionais de saúde. OBJETIVO: Descrever o desenvolvimento de um programa de educação continuada destinado a profissionais de saúde de nível superior da $A B$, sobre manejo das lesões musculoesqueléticas relacionadas ao trabalho (EDUCAS@T). METODOLOGIA: O desenvolvimento se deu a partir da composição de um comitê de especialistas, diagnóstico situacional do nível de conhecimento da população do estudo e desenho final do programa. RESULTADO: O programa de educação continuada para manejo das lesões musculoesqueléticas relacionadas ao trabalho na $A B$, EducaS@t, contêm quatro módulos de formação com carga horária de 60 horas. O conteúdo inclui desde noções introdutórias, até ferramentas de identificação de riscos ocupacionais para ocorrência das lesões musculoesqueléticas relacionadas ao trabalho e seus encaminhamentos. Acompanha um livro de nome "Programa Educativo em Saúde do Trabalhador para Manejo de Lesões Musculoesqueléticas", de 100 páginas dividas em quatro módulos e 1 estudo de caso. CONCLUSÃO: O programa contempla os conteúdos necessários à promoção da resolutividade de lesões musculoesqueléticas por profissionais de saúde da $A B$, através do ensino participativo.
\end{abstract}

Palavras-chave: Saúde do Trabalhador, Lesões Musculoesqueléticas, Formação continuada. 